\title{
In Vitro Effects of Some Ethanolic Crude Extracts of Medicinal Plants against Colletotrichum gloeospoioides, The Pathogen of Antharacnose Disease in Chilli
}

\author{
Sawatdikarn Sanit ${ }^{1}$
}

\author{
${ }^{1}$ Department of Applied Science, Faculty of Science and Technology \\ Phranakhon Si Ayutthaya Rajabhat University, Phranakhon Si Ayutthaya, Thailand
}

\begin{abstract}
The anthracnose disease is one of the major economic diseases in chilli production of Thailand. The present study was aims to test and evaluate the fungicidal activity of the ethanolic crude extracts from thirty-four medicinal plants were tested against Colletotrichum gloeosporioides (the pathogen of anthracnose disease in chilli of Thailand) by poisoned food technique at $0,2,000,4,000,6,000,8,000$ and 10,000 ppm. The inhibition of mycelial growth was evaluated. From the testing, All the used of thirty-four crude extracts showed significant antifungal activity against C. gloeosporioides. The result showed that the Curcuma aromatica, Zingiber zerumbet, Piper betle, Kaempferia galanga, Rosmarinus officinalis and Origanum vulgare crude extracts showed $100 \%$ inhibition of mycelial growth at all concentrations, whereas, the Wedelia trilobata and Polygonum odoratum crude extracts at $10,000 \mathrm{ppm}$ gave the lowest inhibition of 70 and $82 \%$, respectively. The study noted that the crude extracts namely $C$. aromatica, Z. zerumbet, $P$. betle, K. galanga, $R$. officinalis and $O$. vulgare showed the completely control of mycelial growth against $C$. gloeosporioides (the pathogen of anthracnose disease in chilli). These research pointed the oppurtunities for screening and application of some ethanolic crude extracts for a eco-friendly environmental management and exploited method as the biological control in chilli production.
\end{abstract}

Keywods: Fungicidal Activity, Anthracnose Disease, Colletotrichum Gloeosporioides Medicinal Plants, Ethanolic Crude Extracts, Chilli

\section{Introduction}

Anthracnose disease is one of the major economic disease in chilli production of Thailand and worldwide. Than et al. (2008) reported that the anthracnose disease caused by three pathogens namely $C$. gloeosporiodes, $C$. acutatum and $C$. capsici. The anthracnose disease control in chilli production in Thailand had five methods namely mechanical control, cultural control, biological control, chemical control and integrated control. For the chemical control is the best method for anthracnose disease managements, whereas this method as harmful for environmental condition, product residues and human health (Sawatdikarn, 2016).

Although, the management of anthracnose disease with the application of several fungicides. Filoda (2008) reported the effects of three fungicides (Sarfun 500 SC, Amistar 250SC and Gwarant 500 SC) at 0.010 .20 and $0.40 \%$ ihhibited on the colony growth of C. gloeosporiodes and Nagaraju et al. (2020) reported that carbendazim (25 5075 and 100 $\mu \mathrm{l})$ inhibited on the mycelial growth of $C$. gloeosporiodes (the pathogen of anthracnose in mango).

Fungicides can be controlled the anthracnose disease but the toxicity effects on products in human health and environmental issues are studies. Nowadays, the farmers use the biological control for anthracnose disease control in chilli. Sawatdikarn (2016) noted that the medicinal herb crude extracts for the soil and seed borne pathogen control have attracted wide interest. In general, several researches have been focused on medicinal herb crude extracts to control of plant disease management. (Sawatdikarn, 2011).

Several experiments reported of some plants crude extracts and essential oil for antimicrobial activity. Abera et al. (2011) showed the ethanolic crude extracts of two species (Eucalyptus globules and Eucalyptus

This article is published under the terms of the Creative Commons Attribution License 4.0

Author(s) retain the copyright of this article. Publication rights with Alkhaer Publications.

Published at: http://www.ijsciences.com/pub/issue/2020-10/

DOI: 10.18483/ijSci.2310; Online ISSN: 2305-3925; Print ISSN: 2410-4477 
In Vitro Effects of Some Ethanolic Crude Extracts of Medicinal Plants against Colletotrichum gloeospoioides, The Pathogen of Antharacnose Disease in Chilli

citriodera) to inhibit the mycelial growth of Colletotrichum kahawae (the pathogen of berry disease in coffee) for $64-76 \%$.

Sawatdikarn (2011) studied the antifungal activity of crude extracts of six Zingiberaceae species namely Boesenbergia pandurata, Zingiber officinale, Zingiber cassumunar, Amonum xanthioides, Kaempferia galanga and Amonum krervanh against Curvularia sp. (the pathogen of dirty panicle disease in rice), selected crude extracts of $B$. pandurata at $1,000 \mathrm{ppm}$ showed the highest of mycelail growth inhibition for $57 \%$ and the crude extracts of $A$. Krervanh at $1,000 \mathrm{ppm}$ showed the lowest of mycelail growth inhibition for $43 \%$. Sawatdikarn (2016) noted the crude extract of three medicinal plants namely Curcuma aromatica Syzygium aromaticum and Origanum vulgare showed 100\% inhibition on mycelial growth and spore germination of Alternaria sp. (the pathogen od dirty panicle disease in rice at all concentrations $(1,000-10,000$ ppm) and Palhano et al. (2008) reported that the essential oil of Cymbopogon citratus to inhibited on mycelial growth of $C$. gloeosporioides.

Jun-Young et al. (2006) noted that the antifungal activity of crude extracts from Curcuma longa against three red pepper anthracnose (Colletotrichum coccodes, C. gloeosporioides and C. acutatum). Rahman et al. (2011) reported that the seed extracts and the pulp extracts from Jatropha curcas had higher antifungal activity than whole fruit extracts against C. gloeosporioides (the pathogen of anthracnose in papaya).

Haron et al. (2013) showed that the fungicidal activity of Allamanda spp. crude extracts against C. gloeosporioides (the pathogen of anthracnose in papaya). Meng et al. (2013) impressed that the antifungal activity of crude extracts from Camellia semiserrata against $C$. musae and C. gloeosporioides. Marinho et al. (2018) noted that the fungicidal activity of soapberry (Sapindus saponaria) against C. gloeosporioides (the pathogen of anthracnose in papaya), Biju and Paveena (2018) showed that the antifungal activity of some crude extracts (Jatropha curcas, Ricinus coomunis, Chromolaena odorata and Wedelia chinensis) against C. gloeosporioides (the pathogen of anthracnose in black pepper).

Karunarathna et al. (2018) reported that the antifungal activity of six crude extracts (Mikania micrantha, Tithonia diversifolia, Lantana camara, Clusia rosea, Chromolaena odorata and Clidemia hirta) against C. gloeosporioides (the pathogen of anthracnose of ornamental plants).
For the management on some pathogen $(C$. capsici; the pathogen of anthracnose disease in chilli in Thailand), Sawatdikarn (2016) showed that the three crude extracts namely Curcuma aromatica, Piper betle and Origanum vulgare showed $100 \%$ inhibition of mycelial growth at all concentrations, whereas, the Wedelia trilobata and Polygonum odoratum crude extracts at 10,000 ppm gave the lowest inhibition of 62 and $77 \%$, respectively.

Little information of thirty-four medicinal herb crude extracts on inhibition of mycelial growth of $C$. gloeosporioides (the pathogen of anthracnose disease in chilli). The objective of this research was to evaluate of thirty-four medicinal herb crude extracts on the mycelial growth of $C$. gloeosporioides.

\section{Material and methods}

This work was conducted at Department of Applied Science, Faculty of Science and Technology, Phranakhon Si Ayutthaya Rajabhat University, Phranakhon Si Ayutthaya province during 2017-2018 to determine the fungicidal activity of crude extract of thirty-four medicinal plants including; Kaempferia parviflora, Curcuma aromatica, Cymbopogon nardus, Etlingera littorlis, Anethum graveolens, Sorghum bicolor, Tinospora crispa, Eucatyptus camaldulensis, Carthamus tinctorius, Curcuma lomga, Zingiber zerumbet, Chrysanthemum indicum, Wedelia trilobata, Piper betle, Polygonum odoratum, Laurus nobilis, Coscimum fenesstratum, Astragalus momglolicus, Piper sarmentosum, Moringa oleifera, Kaempferia galanga, Codonopsis pilosula, Cinnamomum verum, Capsicum anпиum, Glycyrrhiza glabra, Paeonia lactifolia, Rosmarinus officinalis, Erythriana variegate, Cymbopogon citratus, Alpinia galangal, Boesenbergia pandurata, Origanum vulgare, Caesalpinia Sappan and Curcuma manga against $C$. gloeosporioides (the pathogen of anthracnose disease in chilli) in sterile distilled water and ethanol treatments by using food poisoned technique (Prasad et al., 2010).

\subsection{Preparation of chilli fruits and Isolation of pathogen}

Chilli fruits were obtained from two locations in Central area of Thailand, Phranakhon Si Ayutthaya and Aungthong Province. C. gloeosporioides from the chilli fruits were isolated and maintained on petri dishs containing in Potato dextrose agar (PDA) and incubated at $25^{\circ} \mathrm{C}$. for 3 days before the tests. The preparation of chilli fruits and the isolation of pathogen followed by the methods of Sawatdikarn (2016). 
In Vitro Effects of Some Ethanolic Crude Extracts of Medicinal Plants against Colletotrichum gloeospoioides, The Pathogen of Antharacnose Disease in Chilli

3.2 Collection and preparation of plants samples Thirty-four medicinal herb crude extracts namely, Kaempferia parviflora, Curcuma aromatica, Cymbopogon nardus, Etlingera littorlis, Anethum graveolens, Sorghum bicolor, Tinospora crispa, Eucatyptus camaldulensis, Carthamus tinctorius, Curcuma lomga, Zingiber zerumbet, Chrysanthemum indicum, Wedelia trilobata, Piper betle, Polygonum odoratum, Laurus nobilis, Coscimum fenesstratum, Astragalus momglolicus, Piper sarmentosum, Moringa oleifera, Kaempferia galanga, Codonopsis pilosula, Cinnamomum verum, Capsicum annuum, Glycyrrhiza glabra, Paeonia lactifolia, Rosmarinus officinalis, Erythriana variegate, Cymbopogon citratus, Alpinia galangal, Boesenbergia pandurata, Origanum vulgare, Caesalpinia Sappan and Curcuma manga was extracted by $90 \%$ ethanol and tested for fungicidal activity on mycelial growth of $C$. gloeosporioides.

Thirty-four medicinal crude extracts used in this study was obtained from four locations in Phranakhon Si Ayutthaya province (Bangban, Wangnoi Bangsai and Bangpa-in) where produce and export of medicinal herb productions. There were washed with tap water and air dried for three days to eliminate surface moisture. Then each part of medicinal plants were packed in to envelop and kept in oven at $80^{\circ} \mathrm{C}$ temperature until dried. Dried each parts were grinded separately in an electic grinder to obtain powder which was than kept in plastic bags before the tests (Sawatdikarn, 2016).

\subsection{Preparation of crude extracts}

One hunderd grams of the dried powdered plant were soaked in $1,000 \mathrm{ml}$ of $90 \%$ ethanol. These mixtures were refluxed followed by agitation at $200 \mathrm{rpm}$ for 1 hour. The ethanolic extracts were squeezed and filtered by muslin cloth. The crude extracts were placed in to a wide tray to evaporate ethanol and added with water plant extracts (Prasad et al., 2010)

3.4 Mycelial growth test ; Food poisoned technique; Diffusates were added in PDA and poured into petri dishes. PDA medium added only with ethanol and water served as control treatment. Each petri dishes was inoculated with $5 \mathrm{~mm}$ plug of pure isolate taken from margins of actively growing culture of pathogen. All petri dishes were incubated at $25^{\circ} \mathrm{C}$. (Sawatdikarn, 2016)

The screening of crude extracts for fungicidal activity was conducted using the agar dilution method. Different crude extracts were tested using food poisoning technique. Each tested crude extracts was used at different concentrations; 0 (control treament), 2,000, 4,000, 6,000, 8,000 and 10,000 ppm. The petri dishes were incubated in room temperature for 7 days. The efficacy of treament was assessed from all the four plate by mesuring fungal colony development $(\mathrm{cm})$. The mycelial growth inhibition (M) with respect to the control treament was calculated from the formula (Sheng-Yang et al., 2005; Sawatdikarn, 2016)

$\mathrm{M}=[(\mathrm{A}-\mathrm{B}) / \mathrm{A}] \mathrm{x} 100$

Where $\mathrm{A}$ is the colony diameter of the control treament and B is the colony diameter of the treated of crude extracts.

\subsection{Statistical analysis}

All experiments were done for four replications. Data (inhibition of mycelial growth at 2,000, 4,000, 6,000, 8,000 and $10,000 \mathrm{ppm}$.) were subjected to analysis using Duncan 's Multiple Range Tests (DMRT).

\section{Results and discussion}

The thiry-four medicinal plant crude extracts showed inhibition on mycelial growth of $C$. gloeosporioides at different concentrations (Table 1). The crude extracts of $C$. aromatica, Z. zerumbet, $P$. betle, $K$. galanga, $R$. officinalis and O. vulgare showed $100 \%$ inhibition of mycelial growth at all concentrations, whereas, the $W$. trilobata and $P$. odoratum crude extracts at $10,000 \mathrm{ppm}$ gave the lowest inhibition of 70 and $82 \%$, respectively.

For the $C$. aromatica crude extracts showed 100\% inhibition on mycelial growth at all concentration (Table 1) can be used crude extracts of these species for C. gloeosporioides management (the pathogen of anthracnose disease in chilli) (1,000-10,000 ppm). These results are in agreement with that the researches of Sawatdikarn (2016) noted that the $C$. aromatica crude extracts showed $100 \%$ inhibition on mycelial growth at 5,000-10,000 ppm for $F$. semitectum control (the pathogen of dirty panicle disease in rice) and related to the data of $C$. aromatica crude extracts showed $100 \%$ inhibition on mycelial growth at 5,000-10,000 ppm for C. lunata control (the pathogen of dirty panicle disease in rice) (Sawatdikarn, 2016) and the C. aromatica crude extracts showed $100 \%$ inhibition on mycelial growth at 1,000-10,000 ppm for C. capsici control (the pathogen of anthracnose disease in chilli) (Sawatdikarn, 2016)

The $C$. aromatica crude extracts showed the inhibition on mycelial growth of C. gloeosporioides, the results are in agreement with two researches, Saleem et al. (2011) reported the crude extracts of C. aromatica at $0.4 \%$ showed the completely inhibition on mycelial growth of three pathogen 
In Vitro Effects of Some Ethanolic Crude Extracts of Medicinal Plants against Colletotrichum gloeospoioides, The Pathogen of Antharacnose Disease in Chilli

namely Staphylococcus aureus, Enterococus faecalis and Pseudomonas aeruginosa and Harit et al. (2013) impressed that the ethanolic extract of $C$. aromatica was found to have both antibacterial activity $(S$. aureus and Bacillus subtilis) and antifungal activity (Candida albicans and Aspergillus flavus).

For the Z. zerumbet crude extracts showed $100 \%$ inhibition on mycelial growth at all concentration (Table 1) can be used crude extracts of these species for C. gloeosporioides control (the pathogen of anthracnose disease in chilli) (1,000-10,000 ppm). These results are in agreement with that Sawatdikarn (2016) noted that the plants species (The Zingiberaceae species), the two crude extracts namely $Z$. zerumbet and C. longa showed $100 \%$ inhibition on mycelial growth at 5,000-10,000 ppm for $F$. semitectum control (the pathogen of dirty panicle disease in rice).

The $Z$. zerumbet crude extracts showed the inhibition on mycelial growth of $C$. gloeosporioides, the results are in agreement with some researches, Singh et al. (2014) impressed that the the essential oil of the rhizome of $Z$. zerumbet showed the inhibition on mycelial growth of Cryptococcus neoformans and Kader et al. (2011) noted that the ethanolic extract from rhizome of $Z$. zerumbet showed the antifungal activity of the three pathogens (Candida albicans, Aspergillus niger and Sacharomyces cerevaceae).

Mukherjee et al. (2011) showed the crude extract of Zingiber officinale on the mycelial growth of $C$. gloeosporioides (the causal agent of anthracnose in mango) and Ademe et al. (2011) reporded the fungicidal activity of Zingiber officinale crude extract against $C$. gloeosporioides (the pathogen of anthracnose in papaya (Carica papaya)).

For the $P$. betle crude extracts showed $100 \%$ inhibition on mycelial growth at all concentration (Table 1) can be used crude extracts of these species for C. gloeospoioides control (the pathogen of anthracnose disease in chilli) (1,000-10,000 ppm). These results are in agreement with that the researches of Sawatdikarn (2016) impressed that the $P$. betle crude extracts showed $100 \%$ inhibition on mycelial growth at 2,500-10,000 ppm for $F$. semitectum control (the pathogen of dirty panicle disease in rice) and related to the researchs of $P$. betle crude extracts showed $100 \%$ inhibition on mycelial growth at 2,500-10,000 ppm for Curvularia lunata control (the pathogen of dirty panicle disease in rice) (Sawatdikarn, 2016)

Johnny et al. (2010) stated that the antifungal activity of Piper betle crude extract also showed high inhibition against $C$. gloeosporioides (the causal agent of anthracnose disease in mango). Sawatdikarn (2016) noted that the $P$. betle crude extracts showed $100 \%$ inhibition on mycelial growth at $1,000-10,000$ ppm for C. capsici control (the pathogen of anthracnose disease in chilli).

The $P$. betle crude extracts showed the inhibition on mycelial growth of $C$. gloeosporioides, the results are in agreement with some researches, Ali et al. (2010) focused the crude extract from the leaves of $P$. betle showed the strongly inhibition on mycelial growth of Candida albican and Candida glabrata and Neela et al. (2011) showed that the ethanolic extract from the leaves of $P$. betle at 20 and $25 \%$ concentrations showed the completely inhibition of mycelial growth on Fusarium oxysporum (the causal agent of fusarium wilt disease in tomato).

For the $K$. galanga crude extracts showed $100 \%$ inhibition on mycelial growth at all concentration (Table 1) can be used crude extracts of these species for $\quad$ C. gloeospoioides control (the pathogen of anthracnose disease in chilli) (1,000-10,000 ppm). These results are in agreement with in some the researches, Kochuthressia et al. (2012) reported that the ethanolic crude extract from rhizome of $K$. galangal inhibited of mycelial growth in the four fungal pathogens namely Aspergillus niger, A. flavus, A. fumugatus and Candida albicans and Umar et al. (2011) noted that the $K$. galanga crude extracts have been found to inhibit of mycelial growth in some microorganisms such as Candida albicans, Escheriachia coli, Salmonella typhi and Enterococcus faecalis

For the $R$. officinalis crude extracts showed $100 \%$ inhibition on mycelial growth at all concentration (Table 1) can be used crude extracts of these species for C. gloeospoioides control (the pathogen of anthracnose disease in chilli) (1,000-10,000 ppm). These results are in agreement with that the researches of Sawatdikarn (2016) impressed that the $R$. officinalis crude extracts showed 100\% inhibition on mycelial growth at 2,500-10,000 ppm for $F$. semitectum control (the pathogen of dirty panicle disease in rice) and these data related to the researchs of $R$. officinalis inhibited of some pathogens, Centeno et al. (2010) noted that the crude extracts of $R$. officinalis showed $100 \%$ inhibition on mycelial growth at all concentrations (0.004-0.4\%) for two pathogens control (Aspergillus flavus and $A$. ochraceus) and Matsuzaki et al. (2013) reported that the essentail oil from $R$. officinalis had an effect on mycelail growth of Candiada albicans.

In agreement with this research, Alemu et al. (2014) noted that the methanol extract of $R$. officinalis has 
In Vitro Effects of Some Ethanolic Crude Extracts of Medicinal Plants against Colletotrichum gloeospoioides, The Pathogen of Antharacnose Disease in Chilli

focused fungicidal activity against $C$. gloeosporioides (the pathogen of anthracnose disease in mango).

For the $O$. vulgare crude extracts showed $100 \%$ inhibition on mycelial growth at all concentration (Table 1) can be used crude extracts of these species for C. gloeospoioides control (the pathogen of anthracnose disease in chilli). These results are in agreement with that the researches of Sawatdikarn (2016) noted that the $O$. vulgare crude extracts showed $100 \%$ inhibition on mycelial growth at all concentrations for $F$. semitectum control (the pathogen of dirty panicle disease in rice) and related to the researchs of $O$. vulgare crude extracts showed $100 \%$ inhibition on mycelial growth at all concentrations for $C$. lunata control (the pathogen of dirty panicle disease in rice) (Sawatdikarn, 2016) and these results are in agreement with that the researches of Sawatdikarn (2016) noted the crude extract of $O$. vulgare showed $100 \%$ inhibition on mycelial growth and spore germination of Alternaria $\mathrm{sp}$. (the pathogen od dirty panicle disease in rice at all concentrations (1,000-10,000 ppm) and Lee et al. (2001) tested essential oils of $O$. vulgare for their antimicrobial activities against four plant pathogens (Botrytis cinerea, C. gloeosporioides, Pythium altimum and Rhizoctonia solani), selected essential oils of $O$. vulgare showed the inhibition of mycelial growth for $90 \%$ of C. gloeosporioides.

Sawatdikarn (2016) noted that the $O$. vulgare crude extracts showed $100 \%$ inhibition on mycelial growth at 1,000-10,000 ppm for C. capsici control (the pathogen of anthracnose disease in chilli) and the data related to the researchs of $O$. vulgare crude extracts showed $100 \%$ inhibition on mycelial growth at $2.50 \mathrm{~mL} / 100 \mathrm{~mL}$ for three pathogen control (Pencillium aurantiogriseum, $P$. glabrum and $P$. bravicompactum (Kocic-Tanackov et al., 2011).

For the E. camaldulensis crude extracts at 2,000$8,000 \mathrm{ppm}$ showed the inhibition on mycelial growth for $65-82 \%$ (Table 1). This agreed with the results of Abera et al (2011) showed the ethanolic crude extracts of Eucalyptus globules and Eucalyptus citriodera to inhibit the mycelial growth of Colletotrichum kahawae (the pathogen of berry disease in coffee) for $64-76 \%$.

In the present study, extrect from Moringa oleifera $(2,000-8,000 \mathrm{ppm})$ showed the inhibition on mycelial growth for $58-75 \%$ (Table 1). This agree with the data of Dissanayake et al. (2019) showed the crude extracts of $M$. oleiferato inhibit the mycelial growth of $C$. gloeosporioides (the pathogen of anthracnose disease in papaya) for $35-44 \%$.
The ethanolic crude extract from lemon grass $(C$. citratus) showed the highest antifungal activity (100\% inhibition of mycelial growth) against $C$. gloeosporioides (Table 1). This data corresponds with research done by Perez-Cordero et al. (2017) who reported that extract of $C$. citratus have antifungal activity and inhibit the growth of $C$. gloeosporioides (the pathogen of anthracnose disease in yam) and this agree with the data of Palhano et al. (2004) exhibited the essential oil from lemon grass $(C$. citratus) inhibit the mycelial growth of $C$. gloeosporioides.

For the two crude extracts ( $W$. trilobata and $P$. odoratum) at $10,000 \mathrm{ppm}$ concentration gave the lowest inhibition of 70 and $82 \%$, respectively (Table $1)$. These results are in agreement with that the researches of Sawatdikarn (2016) noted the crude extract of $W$. trilobata and $P$. odoratum showed 62 and $77 \%$ inhibition, respectively on mycelial growth of $C$. capsici (the pathogen of anthracnose disease in Chilli) at 10,000 ppm concentration. Inaddition, Biju and Praveena (2018) reported that the crude extract of $W$. chinensis showed 17-33 inhibition on mycelial growth of $C$. gloeospoioides (the pathogen of anthracnose disease of black pepper) at 2.5510 and $20 \%$ concentrations.

The goal of this study was to screening of the thirtyfour crude extracts on the mycelial growth of $C$. gloeospoioides. The management of all crude extract was the best for $C$. gloeospoioides control due to their harmless on enviromental condition, to user and to consumer. The study that the related to the several researcher have noted the antifungal activity of crude extracts and essential oils including, the researchs of Sawatdikarn (2016) noted the crude of plant species namely Curcuma aromatica, Piper betle and Origanum vulgare crude extracts showed $100 \%$ inhibition of mycelial growth at all concentrations.

Sawatdikarn (2016) impressed that the crude of plant species namely Curcuma aromatica, Piper betle and Origanum vulgare crude extracts showed $100 \%$ inhibition of mycelial growth of $C$. capsici (the pathogen of anthracnose disease in chilli) at all concentrations.

The phytochemical compounds from the six crude extracts (C. aromatica, Z. zerumbet, $P$. betle, $K$. galanga, $R$. officinalis and $O$. vulgare) inhibited the mycelial growth of $C$. gloeospoioides, these results have been confirmed by several researches, for examples curcumin from the rhizome of $C$. aromatica (Husein et al., 2009), piperine from the leaves of $P$. betle (Sawatdikarn, 2016), 1,8-cineole and camphor from the leaves of $R$. Officinalis (Papajani et al., 2015), zerumbone from the rhizome of $Z$. zerumbet 
In Vitro Effects of Some Ethanolic Crude Extracts of Medicinal Plants against Colletotrichum gloeospoioides, The Pathogen of Antharacnose Disease in Chilli

(Singh et al., 2014), ethyl-cinnamate and 1,8-cineole from the rhizome of $K$. galanga (Umar et al., 2011) and carvacrol and p-cymene from the leaves of $O$. vulgare (Papajani et al., 2015)

This study noted that the thirty-four crude extracts can be use for $C$. gloeospoioides management and can be used the six plants crude extracts for anthracnose disease control. The six crude extracts (C. aromatica, $Z$. zerumbet, $\quad P$. betle, $K$. galanga, R. officinalis and O. vulgare) showed $100 \%$ inhibition of mycelial growth of $C$. gloeospoioides (the pathogen of anthracnose disease in chilli) at all concentrations.
The study noted that the six crude extracts $(C$. aromatica, $Z$. zerumbet, $P$. betle, $K$. galanga, $R$. officinalis and $O$. vulgare) gave the completely control of mycelial growth. In addition, the six crude extracts namely $C$. aromatica, $Z$. zerumbet, $P$. betle, $K$. galanga, $R$. officinalis and $O$. vulgare can be used for anthracnose disease management in chilli production as strongest inhibition crude extract and the two crude extract (W. trilobata and P. odoratum) as weakest inhibition crude extract.

Data of the research pointed the oppurtunities for screening and application of some ethanolic crude extracts for a eco-friendly environmental management and exploited method the biological control of chilli production in Thailand.

Table 1 Efficacy of different concentration of some medicinal plants crude extracts on mycelial growth inhibition of C. gloeospoioides (the pathogen of anthracnose disease in chilli)

\begin{tabular}{|c|c|c|c|c|c|}
\hline \multirow[t]{3}{*}{ Medicinal herb crude extracts } & \multicolumn{5}{|c|}{ Mycelial growth inhibition (\%) } \\
\hline & 2,000 & 4,000 & 6,000 & 8,000 & 10,000 \\
\hline & ppm & ppm & ppm & ppm & ppm \\
\hline 1. Kaempferia parviflora & $70 \mathrm{c}$ & $80 \mathrm{c}$ & $89 b$ & $95 b$ & $100 \mathrm{a}$ \\
\hline 2. Curcuma aromatica & $100 \mathrm{a}$ & $100 \mathrm{a}$ & $100 \mathrm{a}$ & $100 \mathrm{a}$ & $100 \mathrm{a}$ \\
\hline 3. Cymbopogon nardus & $60 \mathrm{e}$ & $77 \mathrm{c}$ & $86 b$ & $89 b$ & $100 \mathrm{a}$ \\
\hline 4. Etlingera littorlis & $50 \mathrm{f}$ & $60 \mathrm{e}$ & $77 \mathrm{c}$ & $88 b$ & $96 \mathrm{ab}$ \\
\hline 5. Anethum graveolens & $60 \mathrm{e}$ & $80 \mathrm{c}$ & $88 b$ & $92 b$ & $100 \mathrm{a}$ \\
\hline 6. Sorghum bicolor & $57 \mathrm{e}$ & $70 \mathrm{~d}$ & $78 \mathrm{c}$ & $82 \mathrm{c}$ & $98 \mathrm{ab}$ \\
\hline 7. Tinospora crispa & $40 f$ & $55 \mathrm{e}$ & $68 \mathrm{~d}$ & $78 \mathrm{c}$ & $89 b$ \\
\hline 8. Eucatyptus camaldulensis & $65 \mathrm{~d}$ & $70 \mathrm{~d}$ & $82 c$ & $95 b$ & $100 \mathrm{a}$ \\
\hline 9. Carthamus tinctorius & $45 f$ & $67 d$ & $76 \mathrm{c}$ & $85 b$ & $100 \mathrm{a}$ \\
\hline 10. Curcuma longa & $75 \mathrm{c}$ & $88 b$ & $94 b$ & $100 \mathrm{a}$ & $100 \mathrm{a}$ \\
\hline 11. Zingiber zerumbet & $100 \mathrm{a}$ & $100 \mathrm{a}$ & $100 \mathrm{a}$ & $100 \mathrm{a}$ & $100 \mathrm{a}$ \\
\hline 12. Chrysanthemum indicum & $70 \mathrm{~d}$ & $80 \mathrm{c}$ & $95 b$ & $100 \mathrm{a}$ & $100 \mathrm{a}$ \\
\hline 13. Wedelia trilobata & $20 \mathrm{~h}$ & $30 \mathrm{~h}$ & $55 \mathrm{e}$ & $60 \mathrm{e}$ & $70 \mathrm{~d}$ \\
\hline 14. Piper betle & $100 \mathrm{a}$ & $100 \mathrm{a}$ & $100 \mathrm{a}$ & $100 \mathrm{a}$ & $100 \mathrm{a}$ \\
\hline 15. Polygonum odoratum & $40 \mathrm{f}$ & $59 \mathrm{e}$ & $72 d$ & $79 \mathrm{c}$ & $82 c$ \\
\hline 16. Laurus nobilis & $67 d$ & $78 \mathrm{c}$ & $89 b$ & $100 \mathrm{a}$ & $100 \mathrm{a}$ \\
\hline 17. Coscimum fenesstratum & $80 b$ & $100 \mathrm{a}$ & $100 \mathrm{a}$ & $100 \mathrm{a}$ & $100 \mathrm{a}$ \\
\hline 18. Astragalus momglolicus & $40 \mathrm{~g}$ & $60 \mathrm{e}$ & $70 \mathrm{~d}$ & $82 c$ & $91 \mathrm{~b}$ \\
\hline 19. Piper sarmentosum & $42 \mathrm{~g}$ & $65 \mathrm{~d}$ & $70 \mathrm{~d}$ & $85 b$ & $97 b$ \\
\hline 20. Moringa oleifera & $58 \mathrm{e}$ & $67 d$ & $75 c$ & $92 b$ & $100 \mathrm{a}$ \\
\hline 21. Kaempferia galanga & $100 \mathrm{a}$ & $100 \mathrm{a}$ & $100 \mathrm{a}$ & $100 \mathrm{a}$ & $100 \mathrm{a}$ \\
\hline 22. Codonopsis pilosula & $50 \mathrm{e}$ & $65 d$ & $78 \mathrm{c}$ & $82 c$ & $96 b$ \\
\hline 23. Cinnamomum verum & $48 \mathrm{f}$ & $64 \mathrm{e}$ & $78 \mathrm{c}$ & $81 \mathrm{c}$ & $100 \mathrm{a}$ \\
\hline 24. Capsicum annuum & $51 \mathrm{e}$ & $62 \mathrm{e}$ & $77 \mathrm{c}$ & $82 c$ & $94 b$ \\
\hline 25. Glycyrrhiza glabra & $55 \mathrm{e}$ & $60 \mathrm{e}$ & $72 d$ & $85 b$ & $100 \mathrm{a}$ \\
\hline 26. Paeonia lactifolia & $40 \mathrm{~g}$ & $52 f$ & $64 \mathrm{e}$ & $77 \mathrm{c}$ & $88 b$ \\
\hline 27. Rosmarinus officinalis & $100 \mathrm{a}$ & $100 \mathrm{a}$ & $100 \mathrm{a}$ & $100 \mathrm{a}$ & $100 \mathrm{a}$ \\
\hline 28. Erythriana variegata & $58 \mathrm{e}$ & $60 \mathrm{e}$ & $67 \mathrm{~d}$ & $75 c$ & $89 b$ \\
\hline 29. Cymbopogon citratus & $55 \mathrm{e}$ & $67 d$ & $77 \mathrm{c}$ & $82 \mathrm{c}$ & $100 \mathrm{a}$ \\
\hline 30. Alpinia galanga & $70 d$ & $80 \mathrm{c}$ & $92 b$ & $100 \mathrm{a}$ & $100 \mathrm{a}$ \\
\hline 31. Boesenbergia pandurata & $75 c$ & $92 b$ & $100 \mathrm{a}$ & $100 \mathrm{a}$ & $100 \mathrm{a}$ \\
\hline 32. Origanum vulgare & $100 \mathrm{a}$ & $100 \mathrm{a}$ & $100 \mathrm{a}$ & $100 \mathrm{a}$ & $100 \mathrm{a}$ \\
\hline 33. Caesalpinia Sappan & $57 \mathrm{e}$ & $68 d$ & $77 \mathrm{c}$ & $90 \mathrm{~b}$ & $100 \mathrm{a}$ \\
\hline 34. Curcuma mangga & $85 b$ & $88 b$ & $100 \mathrm{a}$ & $100 \mathrm{a}$ & $100 \mathrm{a}$ \\
\hline C.V. (\%) & 8.64 & 9.82 & 7.65 & 5.86 & 10.24 \\
\hline
\end{tabular}

In the same column, mean followed by a common letter are not significantly different at the 5\% level by DMRT.

\section{Conclusion}

All the used of thirty-four crude extracts showed significant antifungal activity against $C$. gloeospoioides. The result showed that the $C$. aromatica, Z. zerumbet, $P$. betle, $K$. galanga,
$R$. officinalis and $O$. vulgare crude extracts showed $100 \%$ inhibition of mycelial growth at all concentrations, whereas, the $W$. trilobata and $P$. odoratum crude extracts at $10,000 \mathrm{ppm}$ gave the lowest inhibition of 70 and $82 \%$, respectively. 
In Vitro Effects of Some Ethanolic Crude Extracts of Medicinal Plants against Colletotrichum gloeospoioides, The Pathogen of Antharacnose Disease in Chilli

\section{References}

1. Abera A, Lemessa F \& Multa D : 2011. The antigungal activity of some medicinal plants against coffee berry disease caused by Colletotrichum kahawae. Int. J. Agric. Res. 6:268279

2. Ademe A, Ayalew A \& Woldetsadik K : 2013. Evaluation of antifungal activity of plant extracts against payaya anthracnose (Colletotrichum gloeosporioides). J. Plant Pathol. Microb, 4 :1-4.

3. Alemu K, Ayalew A \& K. Weldetsadik: 2014. Evaluation of antifungal activity of botanicals for poatharvest management of mango anthracnose (Colletotrichum gloeosporioides). International Journal of Life Sciences, 8 :16.

4. Ali I, Khan FG, Suri KA, Gupta BD, Satti NK, Dutt P, Afrin F, Qazi GN, \& Khan IA : 2010. In vitro antifungal activity of hydroxychavical isolated from Piper betle L. Annals of Clinical Microbiology and Antimicrobials, 9: 1-9.

5. Biju CN, \& Praveena R: 2018. Evaluation of plant extracts for antifungal activity against Colletotrichum gloeosporioides, the incitant of leaf blight in small cardamom and anthracnose of black pepper. Journal of Plantation Crops, $46: 92-101$.

6. Centeno S, Calvo MA, Adelantado C, \& Figueroa S : 2010. Antifungal activity of extracts of Rosmarinus officinalis and Thymus vulgaris against Aspergillus flavus and A. ochraceus. Pak. J. Biol. Sci, 13: 452-455

7. Dissanayake MLM, Dahanayaka VS \& Ranasinghe C: 2019. Antifungal potential of some plant extracts against Colletotrichum gloeosporioides causal organism of papaya anthracnose disease. Asian J. Biol. Sci, 12:589-595.

8. Filoda G : 2008. Impact of some fungicides on mycelium growth of Colletotrichum gloeosporioides (Penz.) Penz. \& Sacc. Pestycydy/Pesticides, $3: 109-116$.

9. Harit J, Barapatre A, Prajapati M, Aadil MR. \& Senapati S : 2013. Antimicrobial activity of rgizome of selected Curcuma Variety. Int. J. Life Sci. Bt \& Pharm. Res, 2 :183-189.

10. Haron FF, Sijam K, Omar D. \& Rahmani M : 2013. Chemical composition and screening for antifungal activity of Allamanda spp. (Apocynaceae) crude extracts against Colletotrichum gloeosporioides, causal agent of anthracnose in papaya. Australian Journal of Basic and Applied Sciences, 7:88-96.

11. Husein S, Parhusip A. \& Ramasi EF: 2009. Study on antibacterial activity from Temulawak (Curcuma xanthorrhiza Roxb.) rhizomes against pathogenics microbes cell destruction. J. Applied Industrial Biotechnol. in Tropical Region, $2: 1-4$

12. Johnny L, Yusuf UK, \& Nulit R : 2010. The effect of herbal plant exteact on the growth and sporulation of Colletotrichum gloeosporioides. J. Appl. Biosci, 34 :2218-2224.

13. Jun-Young C, Choi GJ, Lee S, Jang KS, Lin HK, Lim CH, Lee SO, Cho KY. \& Kim J : 2006. Antifungal activity against Colletotrichum spp. of curcuminoids isolated from Curcuma longa L. rhizome. J. Microbiol. Biotechnol, $16: 280-285$.

14. Kader G, Nikkon GF, Rashid MA. \& Yeasmin T: 2011 Antimicrobial activities of the rhizome extract of Zingiber zerumbet Linn. Asian Pac J. Trop Biomed, 1: 409-412.

15. Karunarathna TCM, Damunupola JW. \& Bandara BMR 2018. Screening of selected invasive plant extracts for antifungal activity against Colletotrichum gloeosporioides. $\mathrm{P}$ 21-28. In Proceeding of the 3 rd International Research Symposium on Pure and Applied Sciences. University of Kelaniya, Sri Lanka.

16. Kochuthressia KP, Britto SJ, Jaseentha MO. \& Raphael R : 2012. In vitro antimicrobial evaluation of Kaempferia galangal L. rhizome extract. Am. J. Biotechnol. Mol. Sci, 2: $1-5$.

17. Kocic-Tanakov SD, Dimic GR, Tanakov TT, Pejin DJ, Mojovic LV. \& Pejin JD: 2011. Antifungal activity of Oregano (Origanum vulgare L.) extract on the growth of
Fusarium and Penicillium species isolated from food. Hem. Ind, $66: 33-41$.

18. Lee SE, Park BS, Kim MK, Choi WS, Kim HT, Cho KY, Lee SG. \& Lee HS : 2001. Fungicidal activity of pipernonaline. A piperidine alkaloid derived from long pepper, Piper longum L. against phytopathogenic fungi. Crop protection, 20: 523-528.

19. Marinho GJP, Klein DE. \& Junior CLS : 2018. Evaluation of soapberry (Sapindus saponaria L.) leaf extract against papaya anthracnose. Summa Phytopathol, 44:127-131.

20. Matsuzaki Y, Tsujisawa T, Nishihara T, Nakamura M. \& Kakinoki Y: 2013. Antifungal activity of chemotype essential oils from rosemary against Candida albicans. Open Journal of Stomatology, 3: 176-182.

21. Meng X, Li J, Bi F, Zhu L. \& Ma Z: 2015. Antifungal activities of crude extractum from Camellia semiserrata $\mathrm{Ch}$ (Nanshancha) seed cake against Colletotrichum musae, Colletotrichum gloeosporioides and Penicillium italicum in vitro and in vivo fruit test. Plant Pathol. J, 31 :414-420.

22. Mukherjee A, Khandker S, Islam MR. \& Shahid SB: 2011 Efficacy of some plant extracts on the mycelial growth of Colletotrichum gloeosporioides. J. Bangladesh Agril. Univ, $9: 43-47$

23. Nagaraju RS, Sriram RH. \& Achur R : 2020. Anrifungal activity of carbendazim-conjugated silver nanoparticles against anthracnose disease caused by Colletotrichum gloeosporioides in mango. Journal of Plant Pathology, $102: 39-46$.

24. Neela FA, Sonia IA. \& Shamsi S. 2014. Antifungal activity of selected medicinal plant extract on Fusarium oxysporum Schlechtthe causal agent of fusarium wilt disease in tomato, American Journal of Plant Sciences, 5: 2665-2671.

25. Palhano FL, Vichens TB, Santos RB, Orlando MTD, Ventura JA. \& Fernandes PMB : 2004. Inactivation of Colletotrichum gloeosporioides spores by high hydrostatic pressure combined with citral or lemongrass essential oil Int. J. Food Micro, 95: 61-66.

26. Papajani V, Haloci E, Goci E, Shkrel R. \& Manfredini S 2015. Evaluation of antifungal activity of Origanum vulgare and Rosmarinus officinalis essential oil before and after inclusion in B-cyclodextrine. Int. Pharm. Pharm. Sci., 7: 270-273.

27. Perez-Cordero A, Chamorro L, Vitola-Romero D. \& Hernandez-Gomez J : 2017. Antifungal activity of Cymbopogon citratus against Colletotrichum gloeosporioides. Agron Mesoam, 28:465-475.

28. Prasad MNN, Bhat S. \& Sreenivasa MY : 2010. Antifungal activity of essential oils against Phomopsis azadirachtae-the causative of die-back disease of neem. J. Agric. Technol, 6: 127-133.

29. Rahman MS, Ahnad H, Mohamad MTM. \& Rahman MZA : 2011. Extraction of Jatropha curcas fruits for antifungal activity against anthracnose (Colletotrichum gloeosporioides) of papaya. Afr. J. Biotechnol, 10:9796-9799.

30. Saleem MB, Daniel B. \& Murli K : 2011. Antimicrobial activity of three different rhizomes of Curcuma longa \& Curcuma aromatica on Uropathogens of Diabetic patients. Int. J. Pharm Pharm Sci, 3 : 273-279.

31. Sawatdikarn S : 2016. Antifungal activity of crude extracts of some medicinal plants against Curvularia lunata, The pathogen of dirty panicle disease in rice, p 1232-1242. In 2016 Conference Proceedings on International Congress on Chemical, Biological and Environmental Sciences.

32. Sawatdikarn S: 2011. Antifungal activity of twenty-four medicinal crude extracts against Curvularia sp., The pathogen of dirty panicle disease in rice, p. 1-8. In $37^{\text {th }}$ Congress on Science and Technology of Thailand.

33. Sawatdikarn S : 2016. Fungicidal activity of crude extracts of forty medicinal plants against Fusarium semitectum, The pathogen of dirty panicle disease in rice, p. 593-602. In 2016 Conference Proceedings on International Symposium on Life Science and Biological Engineering. 
In Vitro Effects of Some Ethanolic Crude Extracts of Medicinal Plants against Colletotrichum gloeospoioides, The Pathogen of Antharacnose Disease in Chilli

34. Sawatdikarn S : 2016. Fungicidal potentials of crude extracts of thirty-four medicinal plants against Colletotrichum capsici, The pathogen of anthracnose disease in chilli, p. 566575, In 2016 Conference Proceedings ; Annual Conference Engineering and Applied Science.

35. Sheng-Yang W, Pin-Fun C. \& Shang-Tzen C: 2005. Antifungal activities of essential oil and their constituents from indigenous cinnamon (Cinnamomum osmophloeum) leaves against wood decay fungi, Bioresour. Technol, 96: 813-818.

36. Singh CB, Chanu SB, Lenin K, Swapana N, Cantrell C. \& Ross RA: 2014. Chemical composition and biological

activity of the essential oil of rhizome of Zingiber zerumbet (L.) Smith. Journal of Phamacognosy and Phytochemistry, 3 : 130-133.

37. Than PP, Prihastuti H, Phoulivong S, Taylor PWJ. \& Hyde KD : 2008. Chilli anthracnose disease caused by Colletotrichum species. J. Zhejiang Univ Sci B, 10 : 764-778.

38. Umar MI, Asmawi MZB, Sadikun A, Altaf R. \& Iqbal MA : 2011. Phytochemistry and medicinal properties of Kaempferia galanga L. (Zingiberaceae) extracts. Afr. J. Pharm. Pharmcol, 